\title{
Determination of Pulp and Paper Making Suitability Indices of Some Nigerian Species of Leguminosae: Caesalpinoideae
}

\author{
Ojo Dorcas Olufunmilayo
}

\author{
Department Of Biology, \\ Federal College of Education (Special), Oyo-Nigeria
}

Doi:10.5901/ajis.2013.v2n13p61

\begin{abstract}
Uncontrolled felling of trees for domestic and industrial uses is fast depleting the tropical forests and has led to a continued exploitation of Gmelina arborea Roxb. plantations for fuel wood and timber, a development that is threatening the ecosystem and the survival of the pulp and paper making (PPM) industries in Nigeria. This study proposes an objective method for selecting hardwood species for PPM by statistically comparing the available anatomical and other related data in the reference wood (i.e G. arborea Roxb.) with those of alternative hard wood species. (i.e twe/ve Nigerian species of Caesalpinioideae ). Mature stem branches (8-12cm diameter) of twelve species, representing nine genera of the family were collected at various locations in Oyo state. A similar stem branch of G. arborea Roxb. was collected as a standard raw material for pulp and paper making. Using conventional wood anatomical techniques, nine qualitative and twenty quantitative characters were determined. The means of all the quantitative characters were compared by conducting a One-way classification analysis of variance using the version 17.0 SPSS package. Also t-test conducted indicated a significant difference between data from each of the species of Caesalpinoideae and that of G. arborea. Based on the result of the comparison, a numeric value by which the PPM potential of the alternative hardwood species was precisely defined. Results show that the woods of Caesalpinioideae species investigated are highly suitable wood resources for PPM, virtually all the species can be said to be among the best substitutes for G. arborea each being at least $75 \%$ suitable for papermaking in comparison with G. arborea. The Caesalpinioideae species investigated in order of their preferences for PPM are listed as Tamarindus indica (1.5426), Delonix regia (1.2781), Brachystegia eurycoma (1.1801), Senna sieberiana (1.1565), Bauhinia rufescens (1.1119), Afzelia africana (1.0836), Senna siamea (1.0647), Danielia ogea (1.0400), Piliostigma thoningii (0.9431), Detarium senegalensis (0.9114), Danielia oliveri (0.8423) and Caesalpinia pulcherima (0.7562).
\end{abstract}

Keywords: Suitability Index; Caesalpinoideae; G. arborea; pulp and paper; algorithmic botany

\section{Introduction}

Paper is cellulose, extracted from plant materials the quality of which depends on fineness and brightness of the fibres. Papers are produced from muli bamboo (Melocanna baccifera), sugarcane bargasse (Saccharum officinarum) Exoecaria agallocha, Phragmites karka, Gmelina arborea, Albizia falcataria e.t.c. Also, green jute plant (Cocchorus capsularis and Colitorius ) are being used for making pulp (Walton, 1981). Paper is defined as thin material mainly used for writing upon, printing upon or packaging. It is produced by the amalgamation of fibres, typically vegetable fibres composed of cellulose, which are subsequently held together by hydrogen bonding. While the fibres are usually natural in origin, a wide variety of synthetic fibers, such as polypropylene and polyethylene, may be incorporated into paper as a way of imparting desirable physical properties. The most common source of natural fibres for paper making is wood pulp from pulpwood trees. 
Vegetable fibre materials such as cotton, hemp, linen and rice are also used (Tsuen-Hsuin, 1986). According to Anon, 1984; 1990 in Ogunkunle 2010, Gmelina arborea Roxb. and Eucalyptus species have been found among many Nigerian hardwood species to be suitable for pulp and papermaking ( PPM). In Nigeria, the high cost of newsprint and other paper grades has necessitated a search for suitable pulpwood to support the pulp and paper mill. G. arborea has been exhaustively studied and recognized as suitable for pulp and paper production (Kpikpi, 1989) and is now the most popular pulpwood species in Nigeria (Chow and Lucas, 1988) (Ojo , 2012). This is because of its conformity with the qualities of an ideal pulpwood such as rapid growth rate for economical plantation management, longer than average fibre length, Runkel ratio of less than 1, low basic wood density, low chemical extractives and so on (Ogunkunle, 2010). Therefore in the search for an alternative wood resources for paper production, researchers usually evaluate anatomical and other relevant PPM characteristics in tropical wood samples and define their suitability in relation to the available data on G. arborea wood ( Ogunkunle and Oladele 2008).

Caesalpinioideae is a botanical name at the rank of subfamily, placed in the large family Fabaceae or Leguminosae. Its name was derived from the generic name Caesalpinia. According to Wojciechowski, M.F, Johanna M, and Bruce J. (2006), Caesalpinioideae can be said to be paraphyletic because Papilionoideae and Mimosoideae arose from within it. Therefore, it is likely to be split into several subfamilies, although it is not yet clear what those subfamilies should be. (Wojciechowski, M.F, Johanna M, and Bruce J., 2006; Bruneau, B. F., Forest, P.S., Herendeen, B.B. , Klitgaard, and Lewis ,G.P. , 2001). The 2000 species of sub- family Caesalpinioideae are mostly native to tropical and sub-tropical regions. Nearly all of the taxa are shrubs and trees.

The purpose of this paper is to statistically determine the suitability indices of some species of Caesalpinoideae and compare data on these potential PPM wood resources with one another and with those of the widely - accepted standard raw material, G. arborea using the Suitability Index model to compute the PPM suitability indices of these species of Casalpinoideae.

\section{Materials and methods}

Matured wood of each species of between 8 and $12 \mathrm{~cm}$ thick were collected, cut into blocks of about $10 \mathrm{~cm}$ long. Transverse Section, (T.S), Tangential Longitudinal Section (T.L.S) and Radial Longitudinal Section (R.L.S) of the wood samples of about 10 micron thickness was done using sledge microtome. These sections were stained, mounted in DPX and examined with a monocular light microscope. Some cell dimensions such as fibre length (L), fibre diameter (D), height and width of rays in TLS, diameter and lumen width of vessels, thickness of fibre in TS, and vessel wall thickness were determined with the aid of a calibrated ocular micrometer fitted to the microscope. The other wood characteristics determined included number of cells in ray height and ray width (in TLS), densities of fbre, vessel, ray and parenchyma per $\mathrm{mm}^{2}$, percentage composition of fibre, vessel, parenchyma and ray in the wood of the 12 species of Caesalpinioideae. The sample size in each case was 30 except in such cases as length of isolated vessel members in which the structures were usually few. From the various fibre, vessel, and ray dimensions, a derived ratio namely; the relative fibre length that may be of diagnostic value was computed using the formula:

Relative fibre length (RFL) $=\mathrm{L} / \mathrm{D}$

Where $L=$ fibre length; $D=$ fibre diameter

The percentage composition by volume of wood tissue in respect of fibres, vessels, axial parenchyma and rays were determined from the slides of wood TS. In doing this the ocular cytometer with 100 squares was used. An area of four squares on the cytometer was viewed each time and each tissue type that fell within this area was noted with tally. Twenty-five such observations were made within the 100 squares area. The frequency by volume of a tissue type was determined as a simple percentage of the total number of occurrence within the 100 squares of the cytometer. Four of such slides were observed and the mean value reported. From the percentage tissue composition by volume, some standard ratios such as Fibre-to-Vessel ratio (F/V) 
and Fibres to Non-fibrous tissue ratio (F/NF) were determined (Kpikpi and Olatunji, 1990 and Kpikpi, 1992).

The percentage occurrence of vessels with tylose was also computed from TS of wood. Fifty vessels were randomly observed from prepared slides and the number of those vessels containing tylose was noted. The percentage of this number was then determined from its simple ratio to the total number of observations. From 10 randomly selected fields of view in the wood TLS, the percentage of occurrence of different ray types was calculated. For each field of view, the number of each ray type and the total number of all ray types were first determined. Furthermore, the number of each ray type was noted and its percentage of occurrence calculated from a simple ratio of this number to the total number of observations. The mean of all the fields of view was computed and reported.

The density of vessels, fibres, axial parenchyma and rays also determined per $\mathrm{mm}^{2}$ area of wood. While the slides of wood TS were used for vessels, fibres and axial parenchyma that of TLS was used for ray density determination. In each case, the ocular grid of 100 squares whose dimension had earlier been determined was used. The slides were made to pass under the grid at known objective lenses and the number of cells of each tissue type falling within the grid was counted. This number was then converted into number of such cells in one $\mathrm{mm}^{2}$ of wood by direct proportion, the sample size being 30 .

Moreover, some pulp and paper-based derived ratios were computed. The relevant formulae as variously defined by Wood (1989); Kpikpi and Olatunji (1990) and Uju and Ugwoke (1997) are:

Runkel ratio $=2 \mathrm{C} / \mathrm{I}$

Coefficient of fibre flexibility (or felting coefficient) $=\mathrm{L} / \mathrm{D}$

Where, $L=$ fibre length; $C=$ fibre cell wall thickness; $D=$ fibre diameter ; $I$ = fibre lumen width.

The Conventional Approach to Wood comparison and selection for Pulp and Papermaking:

Using both the mean wood dimensional and qualitative characteristics obtained from Gmelina arborea as a standard, those wood characteristics in the 12 species of Caesalpinioideae were compared with one another and with those of the standard using the orthodox or the descriptive technique. The technique consisted in the use of photographs, and descriptive statements of comparison (Kpikpi and Olatunji, 1990); the use of purely descriptive statements vis-à-vis dimensional data from $G$. arborea and those of the species of Caesalpinioideae placed side by side (Kpikpi and Olatunji,1990; Fuwape,1991; and Kpikpi, 1992), and the use of results of statistical analyses with reference to the charts of the principal fibre dimensional characteristics and their derived ratios (Uju and Ugokwe, 1997).

\subsection{Standard Plant Material}

Mature wood of Gmelina arborea tree was taken as the standard plant material (Ogunkunle , A.T.J, Oladele, F.A. and Ayinde, K. , 2004). Seventeen pulp and paper - based quantitative characteristics (Tables 1 and 2 ) were drawn from this sample, the reference data were then taken to be the most desirable mean values of each of the 17 wood parameters, of which the mature Gmelina arborea tree was representative. The \% tissues by wood volume (i.e. vessels, fibres, parenchyma, ray, F/V ratio and F/NF ratio), were determined in replicates of four while data on the other eleven parameters were taken in replicates of 30 (Ogunkunle, A.T. J, Oladele, F.A. and Ayinde, K., 2004).

\subsection{Experimental Plant Materials}

The experimental plant materials were the wood samples of 12 species of Caesalpinioideae collected (Table 1). From these alternative wood samples, data on the 17 pulp and paper- based wood characteristics were drawn in replicates as in Gmelina arborea wood with the aim of determining their PPM suitability in relation to the standard plant material. The formula used was 
as presented by Ogunkunle, A.T.J, Oladele, F.A. and Ayinde, K. (2004), as follows:

\section{SI $=\sqrt{ }\{\Sigma \varphi j w i\}\{\Sigma \varphi j w j\}$}

\section{$\{\Sigma$ piwi $\}\{\Sigma \mu i w j\}$}

Where : SI= suitability index of experimental wood material

$\varphi \mathrm{j}=$ mean values of the parameters in the alternative wood

$\mu \mathrm{i}=$ mean values of the parameters in the standard wood

$w j=$ projected PPM output values of $\varphi j$

wi $=$ projected PPM output values of $\mu \mathrm{i}$

\section{Results and Discussion}

Tables 1 and 2 show the data obtained from both the reference (G. arborea ) and the alternative ( Caesalpinoideae species) wood samples. The Caesalpinoideae species studied can be listed in order of their preference for PPM as Tamarindus indica, Delonix regia, Brachystegia eurycoma, Senna sieberiana, Bauhinia rufescens, Afzelia africana, Senna siamea, Danielia ogea, Piliostigma thoningii, Detarium senegalensis, Danielia oliveri and Caesalpinia pulcherima, with suitability indices of $1.5426,1.2781,1.1801,1.1565,1.1119,1.0836,1.0647,1.0400,0.9431,0.9114,0.8423$ and 0.7562 respectively. These results show that the woods of Caesalpinioideae species investigated are highly suitable wood resources for PPM. From these results, virtually all the species can be said to be among the best substitutes for $G$. arborea each being at least $75 \%$ suitable for papermaking in comparison with $G$. arborea.

The results of the t-tests conducted indicated a significant difference between data from each of the 12 species of Caesalpinioideae and that of $G$. arborea (Table 3). These results cannot be overemphasized for the fact that the data from Caesalpinioideae species used in the comparisons were the means of the projected PPM outputs for the species rather than the computed suitability indices themselves.

Table 1: Mean proportion by volume of some tissue types in the wood of G.arborea and some Nigerian species of Caesalpinoideae

\begin{tabular}{|c|c|c|c|c|c|c|c|c|c|c|}
\hline \multicolumn{11}{|c|}{ Mean Percentage by Volume Mean Number of cells / $\mathrm{mm}^{2}$} \\
\hline Species & Fibre*(F) & Vessel* $^{*}(\mathrm{~V})$ & Parenchy $(\mathrm{P})^{*}$ & Ray* ( R) & $\mathrm{F} / \mathrm{V}^{*}$ & F/NF* & Fibres & Vessels & Ray & Parenchyma \\
\hline 1. Gmelina arborea & $49.15 \pm 2.24$ & $14.61 \pm 5.05$ & $20.55 \pm 4.21$ & $15.69 \pm 2.53$ & $1.85 \pm 0.64$ & $0.98 \pm 0.10$ & $529^{\mathrm{a}} \pm 27.93$ & $10^{b} \pm 0.69$ & $11^{\mathrm{d}} \pm 0.36$ & $303^{b} \pm 10.01$ \\
\hline 2.Afzelia africana & $21.87 \pm 6.88$ & $10.96 \pm 4.47$ & $48.84 \pm 2.70$ & $18.31 \pm 2.34$ & $1.31 \pm 0.92$ & $0.32 \pm 0.12$ & $452^{a} \pm 26.60$ & $4^{a} \pm 0.04$ & $3^{a} \pm 0.00$ & $168^{a} \pm 10.59$ \\
\hline 3.Bauhinia rufescens & $28.19 \pm 4.16$ & $24.45 \pm 4.78$ & $27.65 \pm 1.29$ & $19.72 \pm 4.10$ & $1.47 \pm 0.62$ & $0.42 \pm 0.08$ & $631^{b} \pm 17.89$ & $25^{\mathrm{e}} \pm 1.28$ & $4^{b} \pm 0.36$ & $198^{a} \pm 6.76$ \\
\hline 4.Brachystegia eurycoma & $18.52 \pm 6.45$ & $11.95 \pm 4.19$ & $48.14 \pm 2.13$ & $21.40 \pm 2.48$ & $3.30 \pm 1.69$ & $0.25 \pm 0.09$ & $408^{a} \pm 9.31$ & $8^{\mathrm{b}} \pm 0.55$ & $3^{a} \pm 0.18$ & $337^{b} \pm 11.14$ \\
\hline 5. Caesalpinia pulcherima & $23.95 \pm 4.36$ & $16.61 \pm 3.43$ & $26.18 \pm 1.76$ & $26.18 \pm 1.76$ & $1.84 \pm 0.69$ & $0.32 \pm 0.08$ & $323^{a} \pm 13.69$ & $38^{f} \pm 1.46$ & $4^{b} \pm 0.18$ & $132^{a} \pm 6.76$ \\
\hline 6.Danielia ogea & $48.85 \pm 12.49$ & $15.47 \pm 4.03$ & $17.46 \pm 4.88$ & $18.21 \pm 10.10$ & $4.35 \pm 1.65$ & $1.3 \pm 0.49$ & $624^{b} \pm 31.04$ & $20^{d} \pm 0.91$ & $3^{a} \pm 0.37$ & $162^{a} \pm 9.49$ \\
\hline 7.Danielia oliveri & $26.40 \pm 7.72$ & $10.82 \pm 4.02$ & $36.41 \pm 1.76$ & $26.37 \pm 4.75$ & $1.05 \pm 0.41$ & $0.42 \pm 0.19$ & $317^{a} \pm 9.49$ & 0.18 & $3^{a} \pm 0.00$ & $83^{a} \pm 2.92$ \\
\hline 8.Delonix regia & $33.29 \pm 2.25$ & $13.55 \pm 4.88$ & $36.14 \pm 3.49$ & $16.98 \pm 2.71$ & $4.02 \pm 1.56$ & $0.51 \pm 0.05$ & $287^{a} \pm 9.49$ & $2^{a} \pm 0.18$ & $3^{a} \pm 0.00$ & $182^{a} \pm 9.13$ \\
\hline 9.Detarium senegalense & $3.85 \pm 3.85$ & $18.45 \pm 12.31$ & $59.74 \pm 5.30$ & $17.96 \pm 5.67$ & $0.00 \pm .00$ & $0.45 \pm 0.05$ & $313^{a} \pm 23.74$ & $4^{a} \pm 0.18$ & $3^{a} \pm 0.18$ & $435^{b} \pm 27.02$ \\
\hline 10. Piliostigma thoningii & $14.72 \pm 9.86$ & $24.62 \pm 12.88$ & $39.60 \pm 5.46$ & $21.08 \pm 4.12$ & $0.39 \pm .40$ & $0.23 \pm 0.17$ & $385^{a} \pm 14.97$ & $7^{b} \pm 0.37$ & $7^{c} \pm 0.18$ & $152^{\mathrm{a}} \pm 5.48$ \\
\hline 11.Senna siamea & $33.55 \pm 5.97$ & $6.58 \pm 3.88$ & $33.33 \pm 4.59$ & $26.55 \pm 2.21$ & $1.13 \pm .66$ & $0.52 \pm 0.08$ & $630^{b} \pm 33.41$ & $14^{\mathrm{c}} \pm 1.09$ & $2^{a} \pm 0.18$ & $148^{a} \pm 11.5$ \\
\hline 12.Senna sieberiana & $32.74 \pm 6.73$ & $15.54 \pm 8.42$ & $32.50 \pm 4.53$ & $19.21 \pm 4.94$ & $2.36 \pm 1.45$ & $0.53 \pm 0.16$ & $331^{a} \pm 24.97$ & $6^{b} \pm 0.91$ & $4^{b} \pm 0.19$ & $369^{b} \pm 16.34$ \\
\hline 13. Tamarindus indica & $21.24 \pm 9.37$ & $10.36 \pm 4.65$ & $31.32 \pm 3.50$ & $37.10 \pm 7.77$ & $8.77 \pm 5.85$ & $0.56 \pm 0.09$ & $1034^{c} \pm 73.58$ & $9^{b} \pm 0.55$ & $4^{b} \pm 0.37$ & $460^{b} \pm 76.87$ \\
\hline
\end{tabular}
$\mathrm{F} / \mathrm{V}=$ Fibre-to- Vessel ratio; $\mathrm{F} / \mathrm{NF}=$ Fibres to nonfibrous tissue ratio $=(\mathrm{F} / \mathrm{V}+\mathrm{P}+\mathrm{R})$;

Table 2: Some pulp and paper-based wood fibre and wood constituent characteristics in G. arborea and some Nigerian species of Caesalpinoideae

Mean Fibre dimensions ( $\mu \mathrm{m})$ Mean fibre - derived ratios

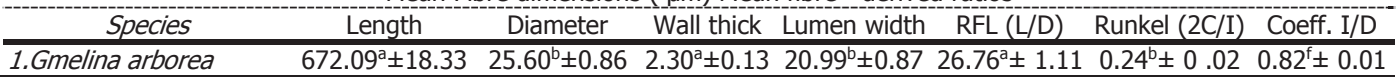




\begin{tabular}{lccccccc}
\hline 2.Afzelia africana & $956.421^{\mathrm{b}} \pm 49.66$ & $11.95^{\mathrm{a}} \pm 0.59$ & $2.39^{\mathrm{a}} \pm 0.08$ & $7.17^{\mathrm{a}} \pm 0.54$ & $89.44^{\mathrm{b}} \pm 8.01$ & $0.79^{\mathrm{a}} \pm 0.08$ & $0.58^{\mathrm{c}} \pm 0.02$ \\
3. Bauhinia rufescens & $936.28^{\mathrm{b}} \pm 32.99$ & $10.50^{\mathrm{a}} \pm 5.68$ & $3.10^{\mathrm{a}} \pm 0.18$ & $4.31^{\mathrm{a}} \pm 0.35$ & $96.49^{\mathrm{b}} \pm 6.91$ & $1.64^{\mathrm{b}} \pm 0.13$ & $0.40^{\mathrm{b}} \pm 0.02$ \\
4. Brachystegia eurycoma & $1079.64^{\mathrm{b}} \pm 39.97$ & $15.70^{\mathrm{a}} \pm 0.61$ & $2.82^{\mathrm{a}} \pm 0.11$ & $10.07^{\mathrm{a}} \pm 0.58$ & $71.23^{\mathrm{b}} \pm 3.57$ & $0.62^{\mathrm{a}} \pm 0.06$ & $0.63^{\mathrm{c}} \pm 0.02$ \\
5.Caesalpinia pulcherima & $747.86^{\mathrm{a}} \pm 25.88$ & $15.53^{\mathrm{a}} \pm 0.51$ & $3.88^{\mathrm{b}} \pm 0.16$ & $7.77^{\mathrm{a}} \pm 0.58$ & $50.34^{\mathrm{b}} \pm 3.06$ & $1.19^{\mathrm{b}} \pm 0.16$ & $0.48^{\mathrm{b}} \pm 0.03$ \\
6.Danielia ogea & $874.16^{\mathrm{b}} \pm 30.52$ & $13.31^{\mathrm{a}} \pm 0.69$ & $3.65^{\mathrm{b}} \pm 0.18$ & $6.02^{\mathrm{a}} \pm 0.52$ & $69.98^{\mathrm{b}} \pm 3.83$ & $1.53^{\mathrm{b}} \pm 0.16$ & $0.43^{\mathrm{b}} \pm 0.02$ \\
7.Danielia oliveri & $950.96^{\mathrm{b}} \pm 23.13$ & $14.08^{\mathrm{a}} \pm 0.61$ & $4.74^{\mathrm{c}} \pm 0.25$ & $4.86^{\mathrm{a}} \pm 0.54$ & $69.29^{\mathrm{b}} \pm 2.87$ & $2.39^{\mathrm{c}} \pm 0.19$ & $0.32^{\mathrm{a}} \pm 0.02$ \\
8.Delonix regia & $1129.93^{\mathrm{b}} \pm 46.79$ & $27.91^{\mathrm{c}} \pm 1.73$ & $3.03^{\mathrm{a}} \pm 0.16$ & $22.19^{\mathrm{b}} \pm 1.75$ & $89.44^{\mathrm{b}} \pm 8.01$ & $0.34^{\mathrm{a}} \pm 0.04$ & $0.75^{\mathrm{d}} \pm 0.02$ \\
9.Detarium senegalense & $621.23^{\mathrm{a}} \pm 28.79$ & $15.45^{\mathrm{a}} \pm 0.48$ & $2.26^{\mathrm{a}} \pm 0.10$ & $10.99^{\mathrm{a}} \pm 0.43$ & $46.46^{\mathrm{b}} \pm 3.59$ & $0.44^{\mathrm{a}} \pm 0.03$ & $0.70^{\mathrm{d}} \pm 0.02$ \\
10.Piliostigma thoningii & $908.29^{\mathrm{b}} \pm 20.27$ & $11.86^{\mathrm{a}} \pm 0.54$ & $3.11^{\mathrm{a}} \pm 0.12$ & $5.55^{\mathrm{a}} \pm 0.48$ & $41.74^{\mathrm{b}} \pm 2.49$ & $1.43^{\mathrm{b}} \pm 0.14$ & $0.45^{\mathrm{b}} \pm 0.02$ \\
11.Senna siamea & $1029.50^{\mathrm{b}} \pm 38.51$ & $15.27^{\mathrm{a}} \pm 0.53$ & $2.99^{\mathrm{a}} \pm 0.13$ & $9.30^{\mathrm{a}} \pm 0.45$ & $82.52^{\mathrm{b}} \pm 3.81$ & $0.68^{\mathrm{a}} \pm 0.04$ & $0.60^{\mathrm{c}} \pm 0.02$ \\
12.Senna sieberiana & $1120.60^{\mathrm{b}} \pm 36.69$ & $11.26^{\mathrm{a}} \pm 0.57$ & $3.95^{\mathrm{b}} \pm 0.24$ & $3.37^{\mathrm{a}} \pm 0.26$ & $70.19^{\mathrm{b}} \pm 3.82$ & $2.70^{\mathrm{c}} \pm 0.19$ & $0.29^{\mathrm{a}} \pm 0.02$ \\
13. Tamarindus indica & $678.57^{\mathrm{a}} \pm 30.08$ & $11.95^{\mathrm{a}} \pm 0.58$ & $3.16^{\mathrm{a}} \pm 0.19$ & $5.63^{\mathrm{a}} \pm 0.51$ & $107.18^{\mathrm{b}} \pm 6.25$ & $1.42^{\mathrm{b}} \pm 0.16$ & $0.46^{\mathrm{b}} \pm 0.03$ \\
\hline
\end{tabular}

RFL= Relative fibre length ( Fibre slenderness); Coeff.= Coefficient of flexibility; Runkel = Runkel ratio ; Means of Caesalpinoideae species with no significant difference from that of $G$. arborea bear the same superscripts with $G$. arborea $(P \geq 0.05)$ while means with significant difference bear a different superscript $(P<0.05)$

Table 3: PPM suitability indices and means of projected PPM suitability values compared for 12 Nigerian species of Caesalpinioideae *

\begin{tabular}{lcccccc}
\hline \multicolumn{1}{c}{ Species } & Suitability index & $\mathrm{t}$ & $\mathrm{df}$ & Mean & Sig.2-tailed & Mean Difference. \\
\hline 1.Afzelia africana & 1.0836 & 2.503 & 19 & 1.5291 & 0.22 & 0.5291 \\
2.Bauhinia rufescens & 1.1119 & 2.265 & 19 & 1.5594 & 0.035 & 0.5594 \\
3.Brachystegia eurycoma & 1.1801 & 2.050 & 19 & 1.3635 & 0.054 & 0.3635 \\
4.Caesalpinia pulcherima & 0.7562 & 2.089 & 19 & 1.3275 & 0.050 & 0.3275 \\
5.Danielia ogea & 1.040 & 2.192 & 19 & 1.4486 & 0.041 & 0.4486 \\
6.Danielia oliveri & 0.8423 & 2.570 & 19 & 1.7917 & 0.019 & 0.7917 \\
7.Delonix regia & 1.2781 & 2.009 & 19 & 1.6010 & 0.050 & 0.6010 \\
8.Detarium senegalense & 0.9114 & 1.603 & 19 & 1.2728 & 0.125 & 0.2728 \\
9.Piliostigma thoningii & 0.9431 & 1.877 & 19 & 1.3142 & 0.760 & 0.3142 \\
10.Senna siamea & 1.0647 & 1.736 & 19 & 1.4600 & 0.099 & 0.4600 \\
11.Senna sieberiana & 1.1565 & 1.892 & 19 & 1.5665 & 0.074 & 0.5665 \\
12. Tamarindus indica & 1.5426 & 1.895 & 19 & 1.4369 & 0.073 & 0.4369 \\
\hline
\end{tabular}

* Test value $=1$; PPM, Pulp and paper making

Figs. 1 to 5 shows the variations in five PPM key parameters of the thirteen woody species studied namely, the mean Fibre-to-Vessel ratio (fig.1), mean Fibre-to-Non-fibrous tissues ratio (fig.2), the mean fibre slenderness ratio (fig3), mean Runkel ratio (fig. 4) and mean coefficient of fibre flexibility (fig. 5).

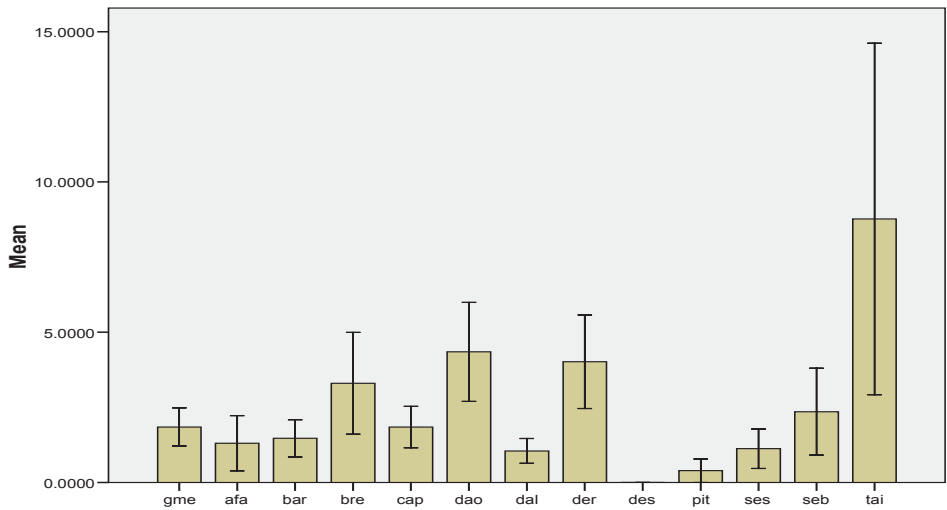

Fig. 1 Variations in the mean Fibre - to - vessel ratios in the wood of 13 tree species studied. 
gme = Gmelina arborea $;$ afa = Afzelia africana; bar = Bauhina rufescens $;$ bre = Brachstegia eurycoma ; cap = Caesalpinia pulcherima $;$ dao = Danielia ogea; dal $=$ Danielia oliveri, der $=$ Delonix regia; des $=$ Detarium senegalensis $;$ pit $=$ Piliostigma thoningii $;$ ses $=$ Senna siamea; seb = Senna sieberiana $;$ tai $=$ Tamarindus indica.

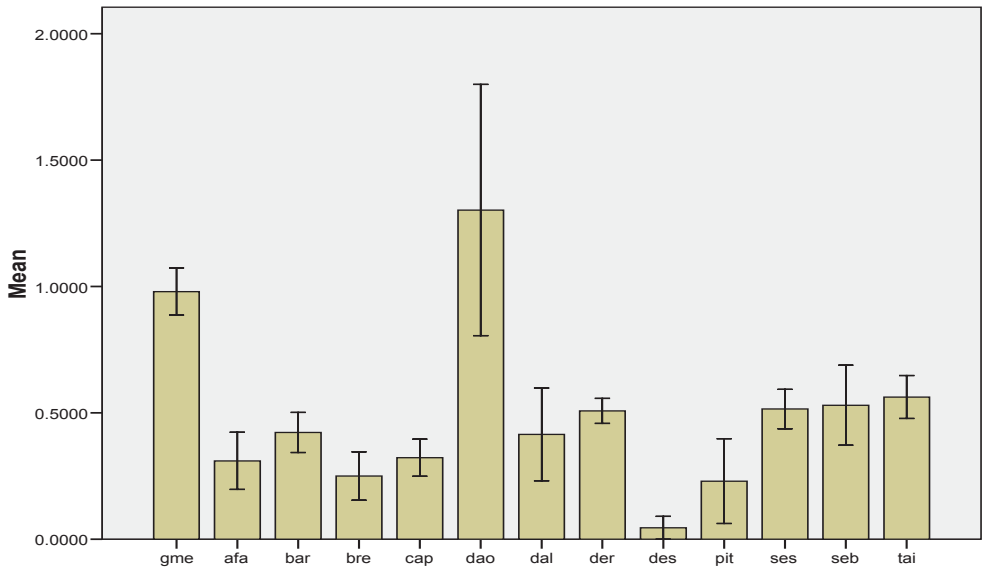

Fig. 2 Variations in the mean Fibre-to-Nonfibrous tissue ratios in the wood of 13 tree species studied.

Error bars: +/- $1 \mathrm{SE}$

gme = Gmelina arborea $;$ afa = Afzelia africana; bar = Bauhina rufescens $;$ bre = Brachstegia eurycoma ; cap = Caesalpinia pulcherima $;$ dao = Danielia ogea; dal $=$ Danielia oliveri, der $=$ Delonix regia; des $=$ Detarium senegalensis $;$ pit $=$ Piliostigma thoningii $;$ ses $=$ Senna siamea; seb = Senna sieberiana ; tai = Tamarindus indica.



gme = Gmelina arborea $;$ afa = Afzelia africana; bar = Bauhina rufescens $;$ bre = Brachstegia eurycoma ; cap = Caesalpinia pulcherima $;$ dao $=$ Danielia ogea; dal $=$ Danielia oliveri; der $=$ Delonix regia; des = Detarium senegalensis $;$ pit = Piliostigma thoningii $;$ ses $=$ Senna siamea; seb = Senna sieberiana ; tai = Tamarindus indica. 


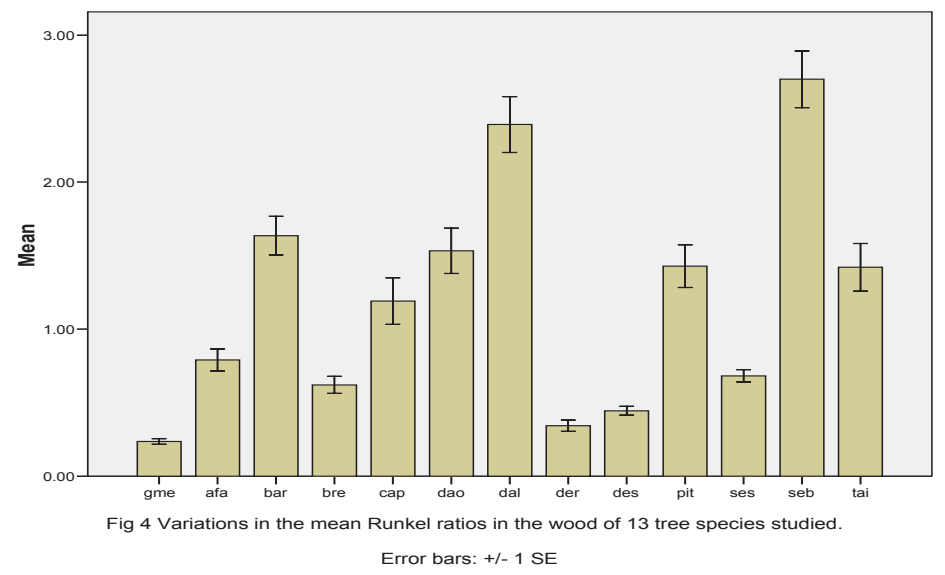

gme = Gmelina arborea $;$ afa = Afzelia africana; bar = Bauhina rufescens $;$ bre = Brachstegia eurycoma $;$ cap = Caesalpinia pulcherima $;$ dao = Danielia ogea; dal $=$ Danielia oliveri, der $=$ Delonix regia; des = Detarium senegalensis $;$ pit = Piliostigma thoningii $;$ ses = Senna siamea; seb = Senna sieberiana ; tai = Tamarindus indica.

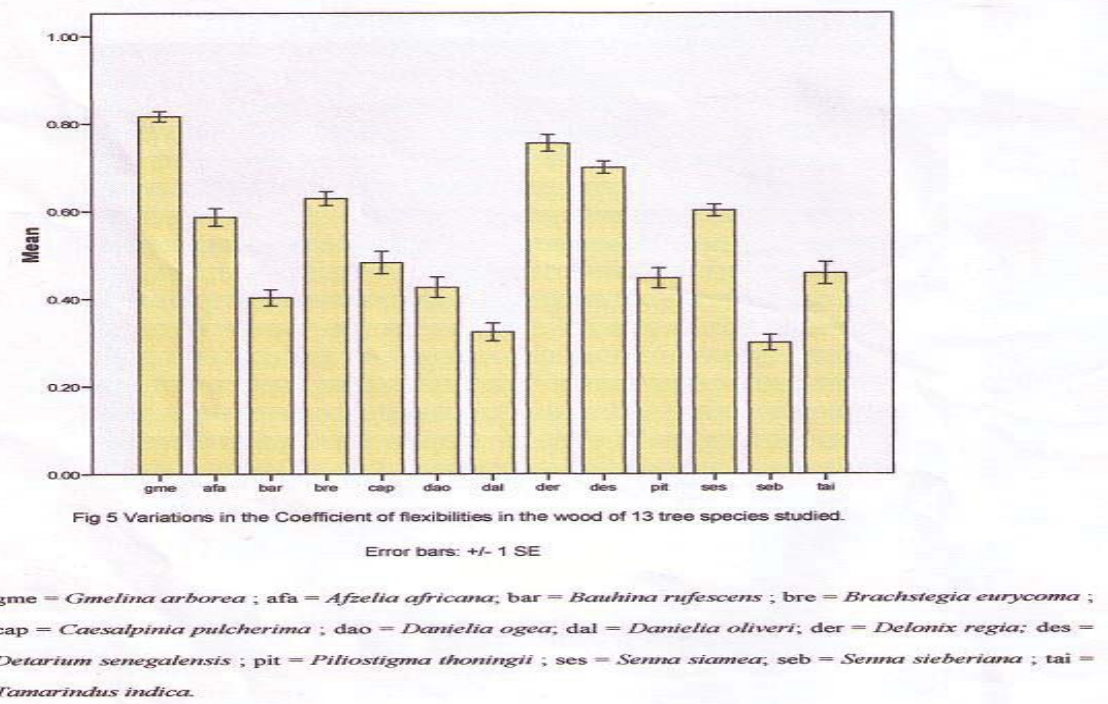

\section{Conclusion}

The pulp and paper making suitability of 12 hardwood species have been quantified, a contribution that has an edge over the conventional method. Moreover, going by the fibre characteristics of eight of the experimental wood samples, (namely, Tamarindus indica, Delonix regia, Brachystegia eurycoma, Senna sieberiana, Bauhinia rufescens, Afzelia africana, Senna siamea, Danielia ogea, with over $100 \%$ suitability index value) the wood can be said to be more suitable raw material than G.arborea in pulp and papermaking. 


\section{References}

Anon, 1984.Chemical Analysis of Nigerian Grown timbers. Annual Report Of The Forestry Research Institute of Nigeria (FRIN). Jan-Dec. 1984 pp:108-109.

Anon, 1990. Raw materials requirements of industries and their local availability. In: Raw Materials Sourcing for Manufacturing in Nigeria. MacMillan Nigerian Publishers, pp: 122.

Bruneau, B. F., Forest, P.S., Herendeen, B.B. , Klitgaard, and Lewis, G.P. (2001). Phylogenetic relationships in the Caesalpinioideae (Leguminosae) as inferred from chloroplast trnLintron sequences. Systematic Botany 26: 487-514

Chow P., and Lucas E.B. (1998). Fuel characteristics of selected four-year-old trees in Nigeria wood and fibre. Science.20 (4) : 431-437

Kpikpi, W. M. (1989). Trema guineesis. an appropriate tropical hardwood for pulp and paper production. TAPPI journal 72 (1): 108- 110

Kpikpi W.M. (1992) Paper making potential of two hard woods. Nigerian Journal of Botany Vol.5 pp 4648.

Kpikpi W.M and Olatunji O.A (1990).Wood anatomy consideration in deciding the suitability of some Nigerian Hardwoods for pulp and paper production. Nigerian Journal of Botany Vol.3 pp 145-149.

Ogunkunle, A.T.J, Oladele, F.A. and Ayinde, K. (2004) . A Model for optimizing the use of Gmelina arborea wood in Pulp and Paper making. Science Focus, Vol.7 pp104 - 112.

Ogunkunle, A.T.J. and Oladele, F.A . (2008). Structural Dimensions and Paper Making Potentials of Wood in Some Nigerian Species of Ficus L. (Moraceae). Advances in Natural and Applied Sciences, 2(3): 103-111.

Ogunkunle, A.T.J. (2010) A quantitative Modeling of Pulp and Paper Making suitability of Nigerian Hardwood Species. Advances in Natural and Applied Sciences, 4(1):14-21.

Ojo, D.O (2012). The diagnostic potentials of wood structure in Leguminosae: Caesalpinioideae.(Unpublished thesis).

Tsuen-Hsuin, T. (1986). "Paper and printing", Vol.5 part 1of Needham Joseph, Science and Civilisation in China: Cambridge university press.

Uju, C. C. and Ugwoke, C.E. (1997). Studies on the dimensions and suitability of wood fibres of selected tree species of the family Moraceae in papermaking. Nigerian Journal of Botany, 10: 7-13

Watson, J.A. (1981). Wood work in Theory and Practice. Anstralasian Publishing Company, London.

Wojciechowski, M. F, Johanna M, and Bruce J. (2006). "Fabaceae". The Tree of Life Web Project. http://tolweb.org/Fabaceae/21093/2006.06.14. 